\title{
The Earliest Discovery of the Role of Magnesium Ions on Stabilizing the Tertiary Structure of the Transfer RNA and Its Biological Significance
}

\section{-A Short Memoir}

\author{
Wangyi Liu \\ Institute of Biochemistry and Cell Biology, Shanghai Institutes for Biological Sciences, The Chinese Academy of Sciences, Shanghai, China \\ Email: wyliu@sibs.ac.cn
}

How to cite this paper: Liu, W.Y. (2016) The Earliest Discovery of the Role of Magnesium Ions on Stabilizing the Tertiary Structure of the Transfer RNA and Its Biological Significance. Advances in Biological Chemistry, 6, 147-151.

http://dx.doi.org/10.4236/abc.2016.65013

Received: July 20, 2016

Accepted: October 24, 2016

Published: October 27, 2016

Copyright $\odot 2016$ by author and Scientific Research Publishing Inc. This work is licensed under the Creative Commons Attribution International License (CC BY 4.0).

http://creativecommons.org/licenses/by/4.0/

\begin{abstract}
In early of 1960s, I was a graduate student studying on tRNA biochemistry. In the course of the research, the magnesium ions stabilized the tertiary structure of tRNA, resulting in its resistance to enzymatic degradation was discovered independently. The experiment of deaminated (denatured) tRNA obtained from native tRNA was designed and conducted and further proved the validity of this finding. It was found that magnesium ions could stabilize the tertiary structure of the natrive tRNA but could not stabilize structure of the deaminated tRNA. In term of the methodology, this stabilization technique has been widely applied in sequencing analysis of RNA and has greatly promoted the progress in the study of primary structure of RNA. More importantly, the stabilization of the tertiary structure of RNA by magnesium ions plays a key role both in the processing of messenger RNAs and the ribozyme activity. After our first article in Chinese was published in 1963, a paper of Nishimura \& Novelli came into our note. The received date of their paper was March 22 of 1963, only 4 days earlier than that of our first paper. Thus, we and Nishimura \& Novelli made almost at the same time the earliest discovery of the role of magnesium ions on stabilizing the tertiary structure of the transfer RNA and thus resulted in resistance of tRNA degradation by enzymes. However, this discovery was not initially appreciated for a period of time but was finally "visualized" and proved by X-ray crystal structure of yeast phenylalanine tRNA, which has provided more accurate information on the geometry of the magnesium-binding sites in tRNA.
\end{abstract}

\section{Keywords}

Deaminated tRNA, Earliest Discovery, Enzymatic Degradation, Magnesium Ion, Tertiary Structure, Transfer RNA 
During 1961-1965, I was a graduate student studying biochemistry in Institute of Biochemistry in Shanghai, of Chinese Academy of Sciences. My supervisor gave me two research projects which were actually unfeasible.

The fist project was biosynthesis of pseudouridine directly from uridine by incubation in an $E$. coli cell-free system. The second one was to find which modified ribonucleosides in the transfer RNA (tRNA) might reduce the degradation rate of tRNA by some RNA hydrolyzing enzymes.

The later project actually was not his original idea, and he just "picked" it up from a paper by Dr. Grunberg-Manag, a French female scientist who became famous owing to her discovery of the well-known enzyme, polynucleotide phosphorylase (PNPase). In that paper, Dr. Grunberg-Manag wrote: "Transfer RNA could not be completely degraded by PNPase and other RNases because the modified nucleosides in tRNA might block enzyme action on tRNA molecule" [1]. Herein, she particularly emphasized the importance of the modified ribonucleosides within tRNA molecule. But this was only her speculation, or, at best, a working proposal. For a long time, my supervisor followed her idea and believed that it was true. Thus, he asked me to identify "the enzymatic product", i.e. to identify which modified ribonucleoside(s) in tRNA molecule blocked the enzyme reaction.

However, Dr. Grunberg-Manag's suggestion was proved to be incorrect by our experimental results. It seems not to be the case because it was found that the modified ribonucleoside itself was actually incapable of resisting the tRNA degradation by RNases. However, the metal ions, such as magnesium ion etc. instead, might be involved in this phenomenon. When my supervisor knew the experimental data indicating the magnesium ions could reduce the rate of enzymatic degradation of tRNA even at higher temperature $\left(60^{\circ} \mathrm{C}\right)$ and that this resisting effect was not due to inhibition of RNase activity because this possibility had already been eliminated, he did not believe the experimental results, and adhered to his opinion. As a new comer, a tough situation of convincing my boss to accept my experimental results was seriously faced to me.

After careful re-examination of the experimental data, it was strongly believed that the magnesium ions stabilized the tertiary structure of tRNA and that this stabilization, in turn, was responsible for the resistance of tRNA to enzymatic degradation. At that time as far as we knew, there were no other reports in the literature showing that magnesium ions could bind to RNA and, thus, resulting in stabilization of RNA structure. In addition, it was not aware any other experimental data concerning RNA in the Institute which could support my results.

In order to validate the experimental results, a convincing way was to destroy the tertiary structure of the native tRNA into the denatured tRNA by some "tricks" and then determine its enzymatic degradation rate in comparison with that of the native tRNA. To this end, the experimental protocol was designed independently and the experiments were performed for obtaining the planted tRNA. The native tRNA was treated with nitrous acid to allow its exhaustive deamination. This treatment resulted in the denaturation (deaminonation) of the native tRNA and thus, the deaminated tRNA was 
obtained successfully in this way. This treatment not only removed the amino groups from the nucleotide bases in tRNA but also destroyed the tertiary structure of tRNA into the denatured (deaminonated) form. Using this technique, two new unusual bases, namely inosine and xanthine, appeared and the tertiary structure of tRNA certainly disappeared. The physical and chemical properties of the denatured tRNA were quite different from those of the native tRNA. Consequently, the enzymatic degradation rate of the denatured tRNA quite different from that of native tRNA was expected: in the presence of magnesium ions, the degradation rate of the denatured tRNA was very faster than that of the native tRNA, indicating that magnesium ions could not stabilize the structure of the denatured tRNA. Furthermore, this was also a strong evidence showing that the newly appeared modified ribonucleosides (inosine and xanothine) could not block the RNase activity, and thus magnesium ions could not stabilize the structure of the denatured tRNA. This result was published first in Chinese and then re-published in English [2] [3].

Now it is well-known that magnesium ions can stabilize the tertiary structure of tRNA as well as other RNAs and its biological significance has been compiled into textbook of modern biochemistry in Chinese and foreign languages. Now nobody would doubt this fact. In term of the methodology, in the presence of magnesium ions, large RNA fragments could be obtained in the enzymatic digestion of tRNA and other big RNA. This classic technique has been widely applied in RNA sequencing analysis and has greatly promoted the progress in the study of the primary structure of RNA. Since Holley et al. [4] published the complete nucleotide sequence of alanine tRNA in 1965, up to 1967 the complete nucleotide sequences of six different tRNA were reported within three years [5]. The rate at which determination of the nucleotide sequences of tRNA is so astonishedly rapid. One of the key technique they used then in work was to get rather large RNA fragments, even half-molecule under the controlled condition (in the presence of magnesium ions). Here, magnesium ions stabilizing the tertiary structure of RNA played an important role [6].

Our first paper was published in Chinese in 1963 and then re-published in English in 1964 [7] [8]. After the first article in Chinese was published [7], a paper by Nishimura \& Novelli [9] caught our attention. The received date of their paper was March 22 of 1963 , only 4 days earlier than that of our first article. Since the same results as ours obtained by the scientists outside country at the same time. My boss was delighted to write a short note to the English version of the article as it was re-published in Scientia Sinica as follows: "After submission of this paper for publication, an article by Nishimura and Novelli came into our attention. These authors studied effect of magnesium ions on the degradation of SRNA by RNases from bovine pancreas and B. subtilis and a similar conclusion that magnesium ions stabilize the secondary structure of $s R N A$ was obtained (January30, 1994)" [8].

In his review article, Dr. Uttam L. RajBhandary, wrote: "Controlled degradation of sRNA with ribonucleases has been studied by Nishimura \& Novelli, who demonstrated that in the presence of magnesium ion, E. coli sRNA was stable to degradation by $B$. subtilis RNase and T1 RNase"[10]. In 1960s in China, due to some particular reasons, 
almost all the scientists in mainland China had no chances to publish their research results in foreign English journals. Thus, we had no choice but to publish our research findings in Acta Biochem. Biophys. Sin. (in Chinese) and then re-published it in Scien. Sin. (in English). Therefore, it is very unlikely that Dr. RajBandary had the chance to access and review our published articles either in Chinese or in English. It is particularly worth noting that from 1965-1968, three reviews published in Nature [11], Federation Proceedings [12], and Progress in Nucleic Acid Research \& Molecular Biology [13], respectively, did give comments on our discovery. The authors highly evaluated our achievements and, in particular, they emphasized that "the use of the deaminated $t R N A$ is a wise idea."

Many years later, a letter with our original papers [2] [3] [7] [8] was sent to Dr RajBandary. He positively responded me as follows: "I consider your papers to be original work published at about the same time as that of Nishimura \& Novelli, also on the effect of $\mathrm{Mg}^{2+}$ on protection of sRNA against degradation by B. subtilis, T1 and pancreatic RNases. The results of your papers also agree with a shift in the melting curve of sRNA towards higher temperature. As you know, the controlled degradation of $s R N A$ by nucleases in the presence of $M g$ was used by Holley and coworkers in their work on sequence analysis of yeast alanine sRNA, for which Holley received the Nobel Prize" (Personal communication, Jan. 15, 2003).

Almost forty years later, a group of British scientists in Cambridge University determined the crystal structure of yeast phenylalanine tRNA to $2.0 \AA$ resolution by X-ray. They reported that the new crystal structure was not only consistent with the previous L-shaped three-dimensional model, but also provided more accurate information on the geometry of the magnesium-binding sites. They had assigned a total of ten magnesium ions in the tRNA molecule [14].

At this point, the binding of magnesium ions to tRNA molecule can be clearly "visualized" by the X-ray crystal structure, and it has been well-known that the binding of magnesium ions to RNA molecules plays a key role in regulating the ribozyme activity and the folding of the self-splicing of mRNA molecules.

\section{Acknowledgements}

The author thanks my former colleagues working together in the same research group during 1961-1965, for their critical reading of the manuscript.

\section{References}

[1] Grunberg-Manago, M. (1959) Phosphorolyse et configuration macromoleculaire des polyribonucleotides biosynthetiques et des acides ribonucleiques. Journal of Molecular Biology, 1, 240-259. http://dx.doi.org/10.1016/S0022-2836(59)80032-2

[2] Liu, W.-I. (W.Y. Liu) and Wang, T.P. (1964) Studies on Soluble Ribonucleic Acids II. Influence of Deamination on the Properties of Soluble Ribonucleic Acids. Acta Biochimica et Biophysica Sinica, 4, 127-136. (In Chinese)

[3] Liu, W.-I. (W.Y. Liu) and Wang, T.P. (1964) Studies on Soluble Ribonucleic Acids II. Influence of Deamination on the Properties of Soluble Ribonucleic Acids. Scientia Sinica, XIII, 1657-1665. (In English) 
[4] Holley, R.W., Apgar, J., Everett, G.A., Madison, J.T., Marquisee, M., Merrill, S.H., Penswick, J.R. and Zamir, A. (1965) Structure of a Ribonucleic Acid. Science, 147, 1462-1465. http://dx.doi.org/10.1126/science.147.3664.1462

[5] Madison, J.T. (1968) Primary Structure of RNA. Annual Review of Biochemistry, 37, 131148. http://dx.doi.org/10.1146/annurev.bi.37.070168.001023

[6] Penswick, J.R. and Holley, R.W. (1965) Specific Cleavage of the Yeast Alanine RNA into Two Large Fragments. Proceedings of the National Academy of Sciences of the United States of America, 53, 543-546. http://dx.doi.org/10.1073/pnas.53.3.543

[7] Liu, W.-I. (W.Y. Liu) and Wang, T.P. (1963) Studies on Soluble Ribonucleic Acids I. The Effects of Metallic Ions on the Resistance of Soluble Ribonucleic Acids against Enzyme Degradation. Acta Biochimica et Biophysica Sinica, 5, 319-328. (In Chinese)

[8] Liu, W.-I. (W.Y. Liu) and Wang, T.P. (1964) Studies on Soluble Ribonucleic Acids I. Effects of Metallic Ions on the Enzymic Resistance of Soluble Ribonucleic Acids. Scientia Sinica, XIII, 463-470. (In English)

[9] Nishimura, S. and Novelli, G.D. (1963) Resistance of S-RNA to Ribonucleases in the Presence of Magnesium Ion. Biochemical and Biophysical Research Communications, 11, 141165. http://dx.doi.org/10.1016/0006-291X(63)90327-9

[10] RajBhandary, U.L. and Stuart, A. (1966) Nucleic Acids-Sequence Analysis. Annual Review of Biochemistry, 35, 759-788.

[11] Errera, M. (1965) Molecular Biology in China. Nature, 205, 739-744. http://dx.doi.org/10.1038/205739a0

[12] Cheng, T.-H. and Doi, R.H. (1968) Advance in Nucleic Acid Research in Communist China. Federation Proceedings, 27, 1439-1454.

[13] Cheng, T.-H. and Doi, R.H. (1968) Recent Nucleic Acid Research in China. Progress in Nucleic Acid Research and Molecular Biology, 8, 335-356. http://dx.doi.org/10.1016/S0079-6603(08)60550-4

[14] Jovine, L., Djordjevic, S. and Rhodes, D. (2000) The Crystal Structure of Yeast Phenylalanine tRNA at 2.0 ̊̊ Resolution: Cleavage by Mg in 15-Year Old Crystals. Journal of Molecular Biology, 301, 401-414. http://dx.doi.org/10.1006/jmbi.2000.3950

Submit or recommend next manuscript to SCIRP and we will provide best service for you:

Accepting pre-submission inquiries through Email, Facebook, LinkedIn, Twitter, etc.

A wide selection of journals (inclusive of 9 subjects, more than 200 journals)

Providing 24-hour high-quality service

User-friendly online submission system

Fair and swift peer-review system

Efficient typesetting and proofreading procedure

Display of the result of downloads and visits, as well as the number of cited articles

Maximum dissemination of your research work

Submit your manuscript at: http://papersubmission.scirp.org/

Or contact abc@scirp.org 